\title{
Tourist Neo-colonialism as an Indication of the Future of Islands. The Example of Borobodur (Central Java)
}

\section{Abstract}

The aim of this paper is to present the process of appropriation of public space by the tourism industry in island states with the example of the temple of Borobudur, addressing the question of the changing trends of the temple's basic functions, from sacred to tourist functions, and the effects of the presented changes on the traditional users of the temple. The Borobudur temple complex has been (symbolically and practically) transferred from the hands of Buddhists into the hands of tourists. The Javanese cultural heritage has been commoditized in a systematic way and lacks religious functions. This is one example of how tourism increasingly appropriates spaces and redefines the meaning of cultural objects. Structural inhibitions to the Borobudur temple being used for traditional religious purposes can be considered an example of tourist neo-colonialism (both from the perspective of postcolonial theory and in light of previous research on the subject).

\section{Keywords}

Tourist Neo-colonialism • Tourism • Postcolonialism • Borobodur • Islands

(C) University of Warsaw - Faculty of Geography and Regional Studies

\author{
Paweł Cywiński
}

Department of World Regional Geography, Institute of Regional and Global Studies Faculty of Geography and Regional Studies, University of Warsaw.

Poland

e-mail: pawel.cywinski@gmail.com

Received: 27 November 2014

Accepted: 8 June 2015
Introduction

The term tourist neo-colonialism (or imperialism) has been appearing for many years in the scientific and popular literature. Tourists are called intruders, the golden horde of our times, modern colonists. These names are often more poetic or emotional than scientific.

In the literature on the subject it is difficult to find a clear definition of tourist neo-colonialism. The easiest answer would be that tourist neo-colonialism is a form of continuation of colonialism, a continuation of the colonial relationship between the former colonies and colonial empires. However, the term tourist neo-colonialism is usually used in a completely different context. This is because the expression neo-colonialism is not always a direct consequence of historical colonialism. In that case, how can it be understood?

To understand the meaning of neo-colonialism, we should first consider the nature of colonialism. To clarify the nature of the relationship we are interested in, I will try to present the outline of the division that occurs at the essence of colonialism.

We were taught in school that colonialism was a political and economic system of exploitation, an export market, a history of European conquest and domination. Teachers told us that, until the 1930s, European colonies and former colonies accounted for $85 \%$ of the world's surface (Loomba 2005); that colonialism was a geo-political process which ended in the last century; that it is just history. However, in my opinion, they did not say the most important thing - that colonialism not only changed the physical territories, but also transformed the areas of social and human identity.

Colonialism was characterized by two channels of dominance. The first was what Ashis Nandy called militaristic (Nandy 1983) and what Abdul JanMohamed (JanMohamed 1985) called the material practice of imperialism. Behind these names, the geopolitical understanding of colonial behaviour is hidden: conquest, exploitation, subordination of the political and economic interests of the colonists. And the colonist here is often understood as a state, a nation or an institution. The second channel is sometimes defined as civilizational or ideological. Abdul JanMohamed called it "the discursive practices of imperialism" - which means the subordination of the cultural and psychological identity of the colonized. More poetically, it is also called the colonization of the mind.

Many postcolonial researchers say that this second path of dominance - imposing colonial structures of thinking, striving to produce a dominant, almost universal, knowledge - is the most important part of building a permanent hierarchy of entities and rule systems in colonial relations (Said 1993, Schiller 1976, Breau at. al 2008, Loomba 2005). I would like to quote two famous opinions. Firstly, I will give voice to Frantz Fanon, who said that the enslavement of the colonized mind, not the guns or the bayonets, is the most solid pillar of colonialism (Fanon 1967). And Ashis Nandy said that modern colonialism won not because of armies and advanced technologies, but their ability to create secular hierarchies inconsistent with the traditional order (Nandy 1983).

Abdul Jan Mohamed argued that the Manichaean dichotomy between the colonized and the colonizer is what shapes the colonial relationship (Jan Mohamed 1985). Frantz Fanon, the most famous psychiatrist who studied colonized minds, wrote likewise - that colonialism is based on creating a Manichean world (Fanon 1961). 
The ideologically designed barrier that separates the colonizer and the colonized is the foundation of the colonized mind. The Manichaeism of the colonial division is based on asymmetric antagonisms descending from two worlds. These oppositions are perfectly visible in the Eurocentric language describing one's own and strangers. They are: colonizer / colonized, civilization / barbarism, centre / periphery, adult / child, European / Savage.

\section{Neo-colonialism}

The economic and political order of the postmodern world is less and less to do with the logic of the 20th century world. However, the colonial issue did not disappear with the recognition of the political independence of former colonies. Many imperialistic and colonial relationships endured after decolonization, and in some cases they even exist today. Therefore, it is even more difficult to define neo-colonialism than colonialism.

The expression 'neo-colonialist' was used publicly for the first time at the end of the process of the political decolonization of Africa. In 1965, Kwame Nkrumah, who was the Marxist ideologist of Pan-Africanism and a powerful Ghanaian politician, published a book entitled "Neo-colonialism, The Last Stage of Imperialism".

In that book he wrote that "In place of colonialism, as the main instrument of imperialism, we have today neo-colonialism... The result of neo-colonialism is that foreign capital is used for the exploitation rather than for the development of the less developed parts of the world. Investment, under neo-colonialism, increases, rather than decreases, the gap between the rich and the poor countries of the world. The struggle against neo-colonialism is not aimed at excluding the capital of the developed world from operating in less developed countries. It is aimed at preventing the financial power of the developed countries being used in such a way as to impoverish the less developed" (Nkrumah 1965).

Many thinkers picked up on that expression, starting to develop the concept and using it in various descriptions of the relationship between the countries that used to be colonized and the former colonial empires. Over time the semantic field of neocolonialism has been extended to the description of a relationship that is beginning to resemble a colonial one, but where a transnational corporation or international institutions are present. However, the majority of those who use this expression, just as in the case of colonialism, have focussed on the materialistic practice of imperialism. For the purpose of my work, I would like to suggest a slightly wider definition of neo-colonialism.

As mentioned before, colonialism can be analysed from two perspectives - the political-military-economic and the psychoidentical-cultural. This division should also be used in the case of neo-colonialism, although - as with colonialism - we more often hear about political and economic neo-colonialism which is visible in the international division of labour, the activities of special forces from the former colonial empires or exploitation by transnational corporations. However, in my opinion, the aspect of neo-colonialism that concerns identity is also very important.

It is also worth noting the considerations of Arjun Appadurai, dedicated to modernity and globalization in his book "Modernity at Large" (Appadurai 1996). He concludes that, in the twentiethcentury world, people used to think according to the categories of territory, space and place. Today, everything is changing. Contemporary globalization, as Zygmunt Bauman believes, is characterized by postmodernism (Bauman 1994), which he understands as an increase in the number of connections between these spaces; the obvious effect of this increase is the deterritorialization of thinking about the world (Appadurai 1996).

Globalization is reflected in the neo-colonial process. Neocolonialism differs from colonialism by the degree of formalization of relations, domination and control. The actors of a neo-colonial relationship are not only governments, states or nations.
Methods of neo-colonial domination are much more subtle and informal, hidden behind formally independent governments, big corporations, informal knowledge and ideas.

For half a century there have been almost no officially colonial states in the world; however, analogous structures of exploitation, like exclusion, imperialism and dominant narratives, still persist. If we tie this together with the ever growing availability of travelling around the world, we can conclude that some informal channels of neo-colonial processes may be increasingly reproduced and distributed in individual and informal contacts. Frequently these contacts occur during touristic meetings. In the global context, meetings between the tourist and the native host do not usually have a 'partner' character - these are not meetings of people treating each other equally, in a subjective way.

In which situations does tourism lack symmetry? What first comes to mind are the economic aspects and the phenomena of leakage or dependence of tourist monoculture on the outside world, as well as the unequal distribution of profits and losses. Tania Nunez, an American anthropologist who has studied the process of acculturation and diffusion of culture and identity, says that, in the case of tourism, we can observe an asymmetric acculturation (Nunez 1989). The tourists borrow less elements than the hosts. Tourism changes the hosts' world more than the tourists'. Dennison Nash notes that tourism is a relationship between the metropolitan centres and tourist regions. Tourist regions are often the product of metropolitan centres. He uses the word "imperialism" to describe this relationship (Nash 1989). When tourists and natives relate to each other objectively, and there is a big difference in social position, a relationship resembling colonialism may occur. There is always a barrier between a hotel guest and a maid. Tourism is a system oriented to satisfy the needs of external metropolitan areas. This is the basic characteristic of the colonial system.

If sustainable tourism should lead to symmetry between tourists and hosts, tourist neo-colonialism leads to the exact opposite. Tourist neo-colonialism occurs when the relationship between a person from outside the local social system (a tourist) and the local host of the meeting is significantly unbalanced or even objectifying. At the same time, the primary goal of this relationship is generally to satisfy the needs of tourists. If the tourist practice does not include relations based on equal conditions, it should be seen as a practice for the privileged - the practice of using the other, the weaker, the poorer. This is how tourism can become a practice of producing winning actors and servile victims.

The next step of my research, in two or three years, will be to identify the specific elements of the relationship between tourists and hosts which can have a neo-colonial character. These include linguistic imperialism, economic dependence, unequal distribution of income, lack of influence on the dominant narrative about him/herself and his/her culture, political subordination and land grabbing.

It is worth adding that sometimes the neo-colonial relationship can also produce positive effects for the local population or part of the local population. These are mostly temporary and of material or infrastructural character - but still, they exist!

\section{Islands}

Trips to tropical islands are now one of the most important destinations of the international tourist market. For many years, islands have been fashionable. In the minds of Western tourists, tropical islands are often the epitome of paradise. This perception dates back to the Romantic period when European adventurers set off to explore the world. The discovered islands fit perfectly into the picture of paradise in the Judeo-Christian tradition. To this day these ideas often have a great impact on the appearance 
and self-creation of the tropical islands. Tourists want to escape from everyday life in the industrialized world and come to the islands attracted by the promise of heavenly rest and relaxation offered by the combination of sun, sand and sea, as well as the ideas of seclusion and the isolation of the islands.

This undoubtedly contributes to an increase in general prosperity, which can be seen even when compared to the GDP of tropical islands (Jędrusik 2005). But an increase in general prosperity is not in contradiction with the development of various elements of tourist neo-colonialism and asymmetric relationships.

I think that this dependency, which leads to a significant lack of symmetry, depends to a great extent on the self-sufficiency of the territory. The less self-sufficient it is, the higher the chances of the occurrence of neo-colonial relations between tourists and hosts, multinational corporations and local companies and politicians. Similarly, the more the area is dependent on tourism, even if it brings profits and prosperity, the greater the chance of neo-colonial relations occurring. Although it should be remembered that on small tropical islands, it was the beginning of investment in the tourist sector that prompted diversification of the economy, which had been often based on the export of single raw materials during the colonial period (McElroy 2003).

It is also worth noting that global tourism has sometimes been the strongest element in the integration of an island into the global capitalist system. In the 1980s tourism was one of the most important elements of the introduction of structural adjustment programs demanded by the International Monetary Fund. To fulfil the adjustment obligations, islands such as Mauritius (1982), the Seychelles (1986), Jamaica (1982, 1984) and Trinidad (1990) had to invest in the development of export strategies, and then move to production and services based on the modern industrial market (de Chavez 1999).

Tourism, even though not a classic commodity, is classified as part of the export strategy in accordance with the International Monetary Fund and the World Bank definitions. These organizations assisted in the reforms of many island states in the second half of the 20th century. Thus, the development of the tourism industry was associated with external global economic trends. One of its important aspects was the pressure on governments to use three important instruments of globalization in the development strategy: finance, communication and transport (Mowforth 2003). For many countries, which had been carrying out reforms according to the instructions of the MF and WB, the fastest and easiest way was to use the ready-made services and to cooperate with corporations from highly-developed countries, which helped their development, but also lead to their dependence and to the high leakage of capital. Those who profited from this process were the local investors and private tourism companies, which often served the interests of foreign capital, but the local community was often marginalized.

At that time the dominant discourse on the impact of tourism on the development process often underestimated the negative effects of fast-growing tourism in developing countries, focussing on highlighting the merits and usefulness.

Island size is a critical problem for many countries, and it is also the main factor limiting the development of tourism. The reasons for this are limitation of resources, small populations and small domestic market, lack of stable economy and dependence on foreign trade. The isolation of these islands results in high transportation costs, considerable trade deficit (meaning the dependence on trade with hegemonic countries), the limitation of well-educated personnel, vulnerability, disproportionately high expenditures on administration and dependence on external institutions in some key services (for example universities and banks) (McKee \& Tisdell 1990, Jędrusik 2005).
The main challenge caused by the appearance of tourism on many islands is to maintain a balance between environmental protection while promoting tourist activities, which certainly influences the environment negatively.

Thus, it is worth noting that, despite its significant role as a tool for local development, tourism on islands is clearly implicated in geographically distant decisions that cannot be controlled locally. When adding the other variables such as geographic location, economic and narrative vulnerability, the likelihood of addiction and the fragility of the ecosystem, the thesis that there is a potential for the existence of neo-colonial relations in the phenomenon of tourism on the small islands can be proved.

\section{Borobudur Temple}

Finally, I would like to pay attention to several elements which show the very local dimension of tourist neo-colonialism associated with the Borobudur temple. In fact, I want to show the diversity of the elements of the tourism phenomena that can be analysed in the context of tourist neo-colonialism.

Borobodur Temple (Candi Borobudur) is a Buddhist temple founded in the 9th century $A D$ in Magelang, Central Java, Indonesia. The monument consists of six square platforms topped by three circular platforms and is decorated with 2,672 relief panels and 504 Buddha statues (Soekmono1976). In 1983 a ten-year process of renovation was completed and the temple was reopened, but with a different character.

Before it was restored, the un-signposted Borobudur was surrounded by villages. It was a part of the villagers' everyday life and was accessible to domestic and foreign tourists, villagers, and hawkers of snacks, sweets and postcards. With the creation of the Tourist Park, within which Borobudur is now situated, the people in the surrounding area were forced to move out, the area was levelled, a fence was put up, and an admission fee is now charged at the entrance (Errington 1993).

Borobudur is now officially a "Monumen Nasional", claimed as a specifically national treasure, a specifically national "heritage". In 1983 it was announced by the government that Buddhists could no longer organize collective ceremonies there. They are allowed to pray collectively only once a year during the holidays of Vesak. For private meditation, they have to purchase a ticket (Errington 1993). In this way Borobudur, one of its most important functions for the last 150 years being a religious one, has been taken away from Indonesian Buddhists and symbolically transferred to domestic and foreign tourists. Today in Indonesia there are more than 2 million Buddhists. Undoubtedly, they have lost their place.

Today's Borobudur is one of the most important tourist symbols of Indonesia and is visited by 2 million tourists a year. $80 \%$ of them are domestic tourists. But ticket prices differ for domestic and foreign tourists. Ticket revenue from foreign tourists accounts for over 70\% of the museum's income (Kausar 2011). It is no wonder that they are an important group of customers at Borobudur and special attractions are prepared for them.

From 2011 tourists entering Borobudur Temple are obliged to wear a batik sarong. This may look like a way of paying respect to a religious place where some tourists could behave inappropriately. But Pujo Suwarno, general manager of Borobudur Tourism Park (TWCB), said in the Jakarta Post that "The concept of wearing sarongs inside the temple is also a tourist attraction for foreigners, so we implemented [the policy]". It is just another illustration of the commercialization of culture and of the transformation from a Buddhist temple to a typical tourist attraction.

In this case the subject of neo-colonization are tourists, as a group participating in commercial practices and being represented by the Indonesian government. The object are Buddhists, as a religious group. One of the differences between neo-colonialism 
and colonialism is, as mentioned above, that neo-colonialism does not necessarily exist between nations or states.

Another example that can be analysed in terms of tourist neo-colonialism is the situation where the neighbours of the Borobudur temple are excluded from the distribution of profits from tourism. The reason for this is that the area around the temple is fenced off and the entire tourist traffic occurs inside the museum complex. Tourists do not need to go beyond the complex of Borobudur. The vast majority of them do not sleep near the temple but about an hour's drive away, in Yogyakarta city, where all traffic and profits from tourism in this part of the island are concentrated (Kausar, Nishikawa \& Nishimura 2011). Tourists spend only three or four hours in the temple of Borobudur. In this case the object of neo-colonization is the local population, excluded from sharing in the profits of neighbouring Borobudur other than from minor services; the subjects once again are the tourists and non-local tourism companies. Some researchers use the name of internal tourist neo-colonialism for such a case.

In both these examples, an asymmetry between the different actors of the phenomenon of tourism can be seen perfectly. The exclusion of certain groups, who would seem to have the right to participate in sharing income and in decision-making processes in the tourism industry, may be an illustration of tourist neo-colonialism. Detailed diversification and the creation of a hierarchy of tourist neo-colonialism are the goals of my future work. I hope soon to be able to measure the phenomenon of tourist neo-colonialism more precisely. This will undoubtedly be an important part of the research on the asymmetric relationships in island tourism, as well as in other destinations.

\section{References}

Appadurai, A 1996, Modernity at Large. Cultural Dimensions of Globalization, University of Minnesota Press, London.

Bauman, Z 1994, Dwa szkice o moralności ponowoczesnej, Instytut Kultury, Warszawa.

Breu, F, Guggenbichler, S \& Wollmann, J 2008, Tourism Development Revisited Concepts, Issues and Paradigms, SAGE Publications, Dehli.

de Chavez, R 1999, Globalisation and tourism: deadly mix for indigenous peoples. Available from: <http://www.twn.my/ title/chavez-cn.htm.> [10 july 2014]

Errington, S 1993, 'Making Progress on Borobudur: an old monument in new order', Visual Anthropology Review, Vol. 9 , no. 2 , pp. 32-59.

Fanon, F 1961, Les Damnés de la terre, ÉditionsMaspero, Paris.

Fanon, F 1967, Black Skin, White Masks, Grove Press, New York.

JanMohamed, AR 1985, 'The Economy of Manichean Allegory: The Function of Racial Difference in Colonialist Literature', Critiqual Intquiry, Vol. 12, no. 1, pp. 59-87.

Jędrusik, M 2005, Wyspy tropikalne. W poszukiwaniu dobrobytu, Wydawnictwo Uniwerystetu Warszawskiego, Warszawa.

Kausar, D., 2011, 'Socio-economic Impacts of Heritage Tourism on Its Locality: A Case Study of Borobudur Temple Compounds World Heritage Site, Central Java'; Forum of International Developmet Studies, Vol. 40, pp. 131-150.

Kausar, D, Nishikawa, Y \& Nishimura, Y 2011, 'How could Management of Borobudur World Heritage Site be Enhances for Improving Tourism Impact for the Community?; A Preliminary Comparison witch Ankgor World Heritage Site', Forum of International Developmet Studies, Vol. 40, pp. 31-42.
Loomba, A 2005, Colonialism/Postcolonialism, Routledge, London.

McElroy, JL 2003, 'Tourism development in small islands across the world'. Geography Annals, 85B(4), pp. 231-242.

McKee, DL \& Tisdell, CA 1990, Developmental issues in small island economies, Praeger, New York.

Mowforth, M \& Munt, I., 2003, Tourism and sustainability: development and New tourism in the Third World, (2nd edition), Routledge, London.

Nandy, A 1983, The Intimate Enemy: Loss and Recovery of Self Under Colonialism, Oxford University Press, Dehli.

Nash, D 1989, 'Tourism as a form of imperialism' (In) Hosts and guests: The anthropology of tourism. (2nd edition). V. Smith, University of Pennsylvania Press, Philadelphia.

Nkrumah, K 1965, Neo-Colonialism, The Last Stage of Imperialism, Thomas Nelson \& Sons, Ltd., London.

Nunez, T 1989, 'Touristic studies in anthropological perspective'. (In) Hosts and guests: The anthropology of tourism. (2nd edition). V. Smith, University of Pennsylvania Press, Philadelphia.

Said, EW 1993, Culture and Imperialism, Vintage Books, London.

Schiller, H 1976, Communication and Cultural Domination, M.E. Sharpe, New York.

Soekmono, R 1976, Chandi Borobudur: A Monument of Mankind, The Unesco Press, Paris. 